www.volsu.ru

DOI: https://doi.org/10.15688/nav.jvolsu.2021.1.2

UDC 903.2

LBC 63.442.6(2)

Submitted: 15.07 .2020

Accepted: 27.05.2021

\title{
BRONZE FLAT ARROWHEADS WITH STINGS FROM THE NORTH BLACK SEA REGION
}

\author{
Sergey D. Lysenko \\ Institute of Archaeology, National Academy of Sciences of Ukraine, Kiev, Ukraine
}

Vitalij S. Sinika

Pridnestrovian State University, Tiraspol, Pridnestrovie, Moldova

\author{
Aleksandr V. Gutsul \\ Pridnestrovian State University, Tiraspol, Pridnestrovie, Moldova
}

\begin{abstract}
The article considers the currently known bronze flat petiolate arrowheads with stings found in the steppe and forest-steppe zones of the Northern Black Sea region, along with new finds. In total, 19 petiolate arrowheads with stings and 3 negatives of similar products on casting molds were taken into account. The distribution area of such items covers the entire western part of the region, between Danube-Carpathian region and the Dnieper basin. The finds are concentrated in the southern part of the Middle Dnieper region (9 items), the North-West Black Sea region (5 items), and the Upper Dniester region (3 items). One arrowhead was found in Podolia and another one was discovered in Northern Bukovina. All currently known casting molds for manufacturing petiolate arrowheads stings come from the North-Western Black Sea region, which allows to localize there one of manufacturing centers. Based on the design features of petiolate, it is proposed to divide all flat petiolate arrowheads with stings into five types. In addition, it is considered the possibility of selecting sub-variants if necessary: by the width of the feather, by the length of the petiole, by the presence of rib in the middle of the feather, by the asymmetry of the stings, by massiveness, etc. Arrowheads of the discussed type, with their archaeological context being reliably known (Magala, Novoselitsa, Volkovka, Gordeevka, Petrikov, Stary Buyukany), are associated with closed complexes of the BrD-HaB1 period (XIII-X centuries BC) in the North Black Sea region. All occasional finds from the region can be dated within these limits. The arrival of bronze petiolate arrowheads with stings in the Northern Black Sea region may have been influenced by contacts with the BalkanCarpathian and Middle Eastern cultural centers. It cannot be ruled out that the regional manufacturing of such arrowheads could be based on imitating local flint implements of the same type, found in various Bronze Age cultures.

Key words: North-West Black Sea region, Middle Dnieper region, Upper Dniester region, Late Bonze Age, bronze arrowheads.

Citation. Lysenko S.D., Sinika V.S., Gutsul A.V., 2021. Bronzovye ploskie chereshkovye nakonechniki strel s zhal'tsami iz Severnogo Prichernomor'ya [Bronze Flat Arrowheads with Stings from the North Black Sea Region]. Nizhnevolzhskiy Arkheologicheskiy Vestnik [The Lower Volga Archaeological Bulletin], vol. 20, no. 1, pp. 20-38. DOI: https://doi.org/10.15688/nav.jvolsu.2021.1.2
\end{abstract}

\section{БРОНЗОВЫЕ ПЛОСКИЕ ЧЕРЕШКОВЫЕ НАКОНЕЧНИКИ СТРЕЛ С ЖАЛЬЦАМИ ИЗ СЕВЕРНОГО ПРИЧЕРНОМОРЬЯ}

\author{
Сергей Дмитриевич Лысенко
}

Институт археологии Национальной академии наук Украины, г. Киев, Украина

\author{
Виталий Степанович Синика
}

Приднестровский государственный университет, г. Тирасполь, Приднестровье 


\section{Александр Вячеславович Гуцул}

Приднестровский государственный университет, г. Тирасполь, Приднестровье

Аннотация. В статье с привлечением новых находок рассмотрены известные на сегодняшний день бронзовые плоские черешковые наконечники стрел с жальцами, обнаруженные в степной и лесостепной зонах Северного Причерноморья. Всего учтено 19 черешковых наконечников стрел с жальцами и три негатива подобных изделий на литейных формах. Ареал распространения таких изделий охватывает всю западную часть региона - между Карпато-Подунавьем и бассейном Днепра. Находки концентрируются в южной части Среднего Поднепровья (9 экз.), Северо-Западном Причерноморье (5 экз.), Верхнем Поднестровье (3 экз.); по одному наконечнику найдено в Подолии и Северной Буковине. Все известные на сегодняшний день литейные формы для изготовления черешковых наконечников стрел с жальцами происходят из Северо-Западного Причерноморья, что позволяет локализовать здесь один из центров по их изготовлению. На основании особенностей конструкции черешка предложено разделение типа плоских черешковых наконечников стрел с жальцами на пять вариантов. Кроме того, рассматривается возможность при необходимости выделения подвариантов: по ширине пера, длине черешка, наличию нервюры в средней части пера, асимметричности жалец, массивности и т. д. В Северном Причерноморье наконечники стрел рассматриваемого типа, контекст находки которых достоверно известен (Магала, Новоселица, Волковка, Гордеевка, Петриков, Старые Буюканы), связаны с закрытыми и замкнутыми комплексами периода $\mathrm{BrD}-\mathrm{HaB}_{1}$ (XIII-X вв. до н.э.). В этих пределах могут быть датированы и все случайные находки из региона. На появление в Северном Причерноморье бронзовых черешковых наконечников стрел с жальцами, возможно, повлияли контакты с балкано-карпатскими и ближневосточными культурными центрами. Нельзя также исключать, что в основе регионального изготовления таких наконечников лежит подражание местным кремневым изделиям такого типа, встречающимся в различных культурах эпохи бронзы.

Ключевые слова: Северо-Западное Причерноморье, Среднее Поднепровье, Верхнее Поднестровье, эпоха поздней бронзы, бронзовые наконечники стрел.

Цитирование. Лысенко С. Д., Синика В. С., Гуцул А. В., 2021. Бронзовые плоские черешковые наконечники стрел с жальцами из Северного Причерноморья // Нижневолжский археологический вестник. Т. 20 , № 1. C. 20-38. DOI: https://doi.org/10.15688/nav.jvolsu.2021.1.2

\section{Введение}

В 2018-2019 гг. коллекцию Археологического музея Приднестровского государственного университета им. Т. Шевченко пополнила значительная серия случайных находок разных периодов, происходящих с территории Слободзейского и Григориопольского районов. Особое место среди находок занимает серия плоских черешковых наконечников стрел с опущенными вниз жальцами [Лысенко и др., 2020].

В процессе поиска аналогий этим находкам выяснилось, что обобщающая работа по таким наконечникам, происходящим из Северного Причерноморья, отсутствует, а все имеющиеся выборки узко региональны и связаны с конкретными археологическими культурами. Это, как и появившийся новый материал, делает актуальным рассмотрение всех наконечников стрел данного типа из макрорегиона в комплексе.

\section{Материалы}

Всего на памятниках степной и лесостепной зон Северного Причерноморья нами учтено 19 черешковых наконечников стрел с жальцами и три негатива подобных изделий на литейных формах.

Приведем ниже описание этих находок по регионам.

СРЕДНЕЕ ПОДНЕПРОВЬЕ.

Волковка (Украина, Черкасская обл., Смелянский р-н, с. Ротмистровка) (рис. 1,11); жилище 3 (белогрудовская культура) (рис. 2,4). В 1991 г. Т.Л. и О.В. Битковскими в придонной части заполнения жилища, на 510 см выше уровня пола, обнаружен бронзовый наконечник стрелы с жальцами и плоским черешком. Черешок расширяется книзу, с выемкой в основании. Длина наконечника (по прорисовке) - 21 мм; размах лопастей - до 15 мм, толщина - до 2 мм; длина черешка - до 9 мм [Куштан, 2013, с. 45, рис. 46,31] ${ }^{1}$. 
В 1986 г. В.П. Ванчугов и И.Т. Черняков выявили серию металлических наконечников стрел позднего бронзового века в коллекциях краеведов В.Е. Баранова и В.Л. Тараненко, которые нашли их при обследовании остатков сабатиновских поселений на левобережье Днепра, разрушаемых интенсивной береговой эрозией Кременчугского водохранилища, у пос. Градижск, сел Кагамлык, Васьковка и Шушваловка Глобинского района Полтавской области ${ }^{2}$. В.П. Ванчугов и И.Т. Черняков отмечают, что эти поселения по керамическому комплексу близки сабатиновскому поселению, исследованному И.Н. Шарафутдиновой у с. Чикаловка недалеко от Кременчуга на правом берегу Днепра [Ванчугов, Черняков, 1991, с. 25]. Однако обратим внимание, что как на Чикаловском поселении, так и на памятниках на размывах левого берега Днепра встречаются материалы разных горизонтов эпохи поздней бронзы - от бабинского до белогрудовско / белозерского, а нахождение наконечников стрел вне комплексов не позволяет однозначно увязывать их именно с сабатиновским горизонтом.

Васьковка (Украина, Полтавская обл., Глобинский р-н) (рис. 1,13). Наконечник стрелы пластинчатый треугольный, с заостренными, опущенными вниз жальцами и коротким черешком (рис. 3,4). Длина наконечника (по прорисовке) - 23 мм; наибольшая ширина пера - 16 мм; длина черешка - 6 мм [Ванчугов, Черняков, 1991 , с. 26 , рис. 1,10$]$.

Градиюсск (Украина, Полтавская обл., Глобинский р-н) (рис. 1,15). Найдено три черешковых наконечника стрел с жальцами.

Наконечник стрель № 1, двухлопастной черешковый, с Т-образной перекладиной на конце черешка (рис. 3,1). Черешок круглый в сечении; продолжение его образует вертикальную нервюру по центру пера. Длина наконечника - 42 мм; наибольшая ширина пера -20 мм; длина черешка - 19 мм, перекладины - 11 мм [Ванчугов, Черняков, 1991, с. 25, рис. 1,4].

Наконечник стрель № 2, пластинчатый треугольный, с заостренными, опущенными вниз жальцами и коротким черешком (рис. 3,2). Длина наконечника (по прорисовке) - 23 мм; наибольшая ширина пера - 16 мм; длина черешка - 5 мм [Ванчугов, Черняков, 1991 , с. 26 , рис. 1,11$]$.
Наконечник стрель № 3, пластинчатый треугольный, с заостренными, опущенными вниз жальцами и коротким черешком (рис. 3,3). Длина наконечника (по прорисовке) - 20,5 мм; наибольшая ширина пера - до 16,5 мм; длина черешка - 7 мм [Ванчугов, Черняков, 1991, с. 26, рис. 1,12].

Кагамлык (Украина, Полтавская обл., Глобинский р-н) (рис. 1,14). Найдено три черешковых наконечника стрел с жальцами.

Наконечник стрель № 1, пластинчатый треугольный, с заостренными, опущенными вниз жальцами и удлиненным черешком (рис. 3,5 ). Длина наконечника - 30 мм; наибольшая ширина пера - 15 мм; длина черешка - 14 мм [Ванчугов, Черняков, 1991, с. 26, рис. 1,7].

Наконечник стрель № 2, пластинчатый треугольный, с заостренными, опущенными вниз жальцами и удлиненным, расширенным к концу черешком с треугольным вырезом в основании (рис. 3,6). Длина наконечника 33 мм; наибольшая ширина пера - 17 мм; длина черешка - 13 мм [Ванчугов, Черняков, 1991 , с. 26 , рис. 1,8$]$.

Наконечник стрель № 3, пластинчатый треугольный, с заостренными, опущенными вниз жальцами и коротким черешком (рис. 3,7). Длина наконечника - 18 мм; наибольшая ширина пера - 17 мм; длина черешка - 5 мм [Ванчугов, Черняков, 1991, с. 26, рис. 1,9].

Шушваловка (Украина, Полтавская обл., Глобинский р-н) (рис. 1,12). Наконечник стрелы пластинчатый треугольный с заостренными, опущенными вниз жальцами и коротким черешком (рис. 3,8 ). Длина наконечника (по прорисовке) - 20 мм; наибольшая ширина пера - 14 мм; длина черешка - 7 мм [Ванчугов, Черняков, 1991, с. 26, рис. 1,13].

\section{ПОДОЛИЯ.}

Гордеевка (Украина, Винницкая обл., Тростянецкий р-н) (рис. 1,4), курган 34 (белогрудовская культура). Бронзовый треугольный наконечник стрелы с коротким, уплощенным проковкой черешком и асимметричными заостренными жальцами (рис. 2,5). Длина (по прорисовке) - 30 см, ширина пера 14 мм; длина черешка - 10 мм [Березанская, Лобай, 1988, табл. XVII,6; Berezanskaja, Kločko, 1998, taf. 66,5; Клочко, 2006, с. 205, 
рис. 96,5; Березанська, Клочко, 2011, с. 33, рис. 66,5$]$.

\section{ГАЛИЦИЯ.}

Вороцев (Украина, Львовская обл., Яворовский р-н) (рис. 1,1$)^{3}$. Из раскопок Л.Г. Мацкевого 1977 г. происходит плоский треугольный наконечник стрелы с небольшими жальцами и длинным черешком; окончание черешка Т-образное неразвитое, подокруглое (рис. 2,9) [Бандрівський, 2014, с. 187, рис. 73,14].

Гончаровка (Украина, Львовская обл., Золочевский р-н), могильник (рис. 1,2). В 1932 г. Я. Пастернаком опубликован и отнесен к высоцкой культуре плоский треугольный наконечник стрелы с небольшими жальцами и длинным черешком, имеющим на конце Т-образное подовальное расширение (рис. 2,8) [Пастернак, 1932, табл. VIII,2; Бандрівський, 2014, с. 187 , рис. 73,13$]$.

Петриков (Украина, Тернопольская обл., Тернопольский р-н) (рис. 1,3), погребение 56 (ранняя высоцкая культура). Над левой частью тазовой кости, на расстоянии приблизительно 7 см, найден бронзовый наконечник стрелы черешкового типа (рис. 2,6). Наконечник плоский, в разрезе - линзовидный (за счет заточки или проковки граней), концы лопастей - острые. Сохранившаяся длина 23-24 мм, размах лопастей 9 мм, длина выступающего черешка 6-7 мм [Бандрівський, 2002, с. 61, рис. $24,1,2$, фото $80 ; 2014$, с. 187 , рис. 73,15$]$.

БУКОВИНА.

Магала (Украина, Черновицкая обл., Новоселицкий р-н) (рис. 1,20), зольник 3 (горизонт Магала II, культура Ноа). В 1957 г. на площади раскопа 5 найден плоский наконечник стрелы с жальцами и длинным черешком (рис. 3,9). Длина наконечника (по прорисовке) - 35,5 мм; наибольшая ширина пера 19 мм; длина черешка - 19 мм [Смирнова, $1957 / 22$, с. 4 , табл. 11,$6 ; 1969$, с. 15 , рис. $7, I, 24]$.

СЕВЕРО-ЗАПАДНОЕ ПРИЧЕРНОMOPbE.

Новоселица (Украина, Одесская обл., Татарбунарский р-н) (рис. 1,10), зольник (поздняя сабатиновская культура). Памятник раскопан в 1975 и 1977 гг. Г.Н. Тощевым. При исследовании зольника был найден черешковый наконечник стрелы с опущенными жальцами и одним шипом на конце черешка (рис. 2,10 ).
Длина - 34 мм (конец обломан); ширина пера 16 мм; длина черешка - 11 мм [Тощев, Черняков, 1986 , с. 128 , рис. 6,4 ; Ванчугов, Черняков, 1991, с. 25 , рис. 1,3$]$.

Старые Буюканы (Молдавия, г. Кишинев) (рис. 1,6), разрушенное погребение (ранний гальштат). Обнаружен в 1982 г. школьниками. Наконечник стрелы с длинным черешком с Т-образным окончанием (рис. 2,7). Лопасти откованы и опущены вниз. Черешок подромбический в сечении; продолжение его образует вертикальную нервюру по центру пера. Длина наконечника - 48 мм, размах лопастей -25 мм. Согласно информации В.А. Дергачева, наконечник был найден в разрушенном погребении вместе с булавкой с петельчатой пластинчатой головкой [Ванчугов, 1990, с. 93, рис. 35,7; Ванчугов, Черняков, 1991, с. 30, рис. 2,4]. Памятник отнесен к раннегальштатской (карпато-дунайской) культуре КишиневКорлатены (Кишинэу-Корлэтень) [Levițki, 1994, fig. 49,17; Бочкарев, Кашуба, 2018, рис. 3] ${ }^{4}$.

Терновка-1 (Приднестровье, Слободзейский р-н), подъемный материал (2019) (рис. 1,8$)$. Наконечник стрелы - плоский черешковый, с плоским черешком и свисающими жальцами (рис. 2,3). Черешок подтрапециевидный в плане, сужается книзу. Продольное и поперечное сечения наконечника линзовидные; сечение черешка подпрямоугольное. На одной плоскости сохранились следы разметки вырубки черешка и жалец. Длина наконечника - 24,5 мм. Размах лопастей 20,5 мм. Толщина - до 0,8 мм. Длина черешка - 10 мм; ширина - 3,4-4,4 мм. Длина жалец -8 и 11 мм; ширина - до 4 мм. Вес наконечника $-0,79$ гр.

Токмазея-1 (Приднестровье, Григориопольский р-н), подъемный материал (2019) (рис. 1,7). На площади карьера между селами Спея и Токмазея найдено два наконечника стрел.

Наконечник стрель № 1, плоский черешковый, с плоским черешком и свисающими жальцами; окончание черешка Т-образное (рис. 2,1). Поперечное сечение наконечника линзовидное; сечение черешка подпрямоугольное. Длина наконечника - 51,7 мм. Размах лопастей - 20,6 мм. Толщина - до 1,7 мм. Длина черешка - до 16 мм; ширина - до 5 мм; толщина - до 1,8 мм. Размеры перекладины 
на конце черешка $-8 \times 2,5$ мм. Длина жалец 7 и 9 мм; ширина - до 4 и 5 мм. Вес наконечника - 3,4 гр.

Наконечник стрель № 2, плоский черешковый, с плоским черешком и свисающими жальцами; с одной стороны нижней части черешка расположен плоский выступ, наклоненный вниз (рис. 2,2). Поперечное сечение наконечника ромбическое; сечение черешка подпрямоугольное. Длина наконечника 49,8 мм. Размах лопастей - 24,7 мм. Толщина - до 3,4 мм. Длина черешка - до 30 мм; ширина - 3,5-5 мм; толщина -0,7-3,4 мм. Размеры выступа на конце черешка: 4,5 × 4 мм, толщина $-0,8$ мм. Длина жалец - 13 и 16 мм; ширина - до 3 и 3,5 мм. Вес наконечника 4,26 гр.

Из Одесской области также происходят две литейные формы с тремя негативами для отливки плоских черешковых стрел с опущенными вниз жальцами (рис. 4).

Слободка (Украина, Одесская обл., Кодымский р-н) (рис. 1,5). Литейная форма, обломок большой матрицы для отливки сразу нескольких наконечников стрел, соединенных последовательно (рис. 4,1). Обнаружена в 1985 г. А.А. Россохацким при обследовании остатков сабатиновского поселения, разрушенного при строительстве дамбы. Форма изготовлена из серпенцито-хлорито-кварцевого сланца ${ }^{5}$. Обломок прямоугольной формы размерами $47 \times 31 \times 19$ мм. На широкой поверхности вырезан ряд негативов двухлопастных черешковых наконечников стрел с заостренными и опущенными вниз жальцами пера треугольной формы. Полностью сохранился только один негатив наконечника стрелы и верхняя часть второго, поскольку нижняя часть литейной формы обломана. Учитывая общие размеры и толщину обломка литейной формы, В.П. Ванчугов и И.Т. Черняков предполагают, что на ней помещалось не менее трех негативов наконечников стрел, расположенных в ряд и соединенных между собой. Их отливка осуществлялась одновременно, после чего производилось их обламывание в месте соединения черешка с наконечником стрелы. Длина негатива - 35 мм, наибольшая ширина пера - 16 мм, длина черешка - 15 мм, ширина - 4 мм, глубина вырезки негатива - 3 мм (рис. 2,11). Негативы обожжены и использо- вались для отливки. Тальковый камень с негативами наконечников стрел использован вторично. На плоских сторонах сохранились остатки прежних негативов от прямоугольного плоского предмета (возможно, долота), часть негатива с треугольным углублением (кельт?), какого-то узкого длинного предмета (шило, браслет). Все прежние негативы обожжены [Ванчугов, 1990, с. 92, рис. 34,2, 35,4; Ванчугов, Черняков, 1991 , с. 25 , рис. 1,2$]$.

Суворово VI (Украина, Одесская обл., Измаильский р-н) (рис. 1,9). Два негатива на разных сторонах одной литейной формы (рис. 4,2). Литейная форма найдена в 1982 г. на позднесабатиновском поселении Суворово VI. Она представляет собой обломок ранее большой литейной формы для отливки однолезвийного ножа типа Н-4 (по Е.Н. Черныху). После поломки при последней переделке литейной формы она была разделена на части прямой линией при помощи «техники сверления в ряд», от которой остались следы шести отверстий. На двух плоскостях оставшегося небольшого куска литейной формы были вырезаны два негатива наконечников стрел. На наиболее широкой плоскости был вырезан негатив черенкового двухлопастного наконечника стрелы (№ 1) с заостренными и слегка разведенными в стороны жальцами и Т-образным окончанием черенка. Длина негатива -45 мм $^{6}$, размах лопастей -27 мм, длина черенка - 20 мм, длина перекладины - 9 мм, ширина черенка - 2,5 мм. Форма, очевидно, была двусторонней, и общая толщина наконечника стрелы составляла 3-4 мм (рис. 2,13). На одной из граней матрицы вырезан еще один негатив аналогичного наконечника меньших размеров (№ 2). Длина его - 20 мм, размах лопастей 15 мм, длина черенка - 13 мм, ширина черенка - 3 мм, глубина вырезки негатива - 1,2 мм (рис. 2,12) [Черняков и др., 1986, с. $48-49$, рис. 2 ; Ванчугов, 1990 , с. 92 , рис. 34,1 , $35,5-6]$.

\section{Типология черешковых наконечников стрел с жальцами}

В.П. Ванчугов и И.Т. Черняков выделяют восемь вариантов типа плоских треугольных наконечников стрел с жальцами [Ванчугов, Черняков 1991, с. 29-30]. 
Ниже попытаемся предложить свое видение на разделение таких наконечников стрел на варианты, взяв за основу типологии особенности конструкции черешка. Выделенные варианты могут быть в случае необходимости разделены на подварианты с применением принципа конструктора: по ширине пера, длине черешка (короткий, средний, длинный), наличию / отсутствию нервюры в средней части пера, асимметричности жалец, массивности и т. д.

Вариант 1. Наконечники с простым черешком различной длины (с параллельными гранями или сужающимся книзу):

- широкие с коротким черешком (Васьковка; Градижск, № 2, № 3; Кагамлык, № 3; Шушваловка);

- широкие с черешком средней длины (Кагамлык, № 1; Терновка; Суворово, негатив 2);

- широкие с длинным черешком (Магала);

- узкие с черешком средней длины (Петриков);

- широкие с нервюрой и черешком средней длины (Слободка, негатив).

Вариант 2. Наконечники с расширяющимся к концу черешком:

- асимметричные без нервюры с черешком средней длины (Гордеевка).

Вариант 3. Наконечники с расширяющимся к концу раздвоенным черешком:

- широкие с черешком средней длины (Кагамлык, № 2);

- широкие асимметричные с черешком средней длины (Волковка).

Bapиант 4. Наконечники с черешком с шипом:

- широкие с длинным черешком (Токмазея, № 2);

- узкие с черешком средней длины (Новоселица).

Bариант 5. Наконечники с черешком с Т-образным окончанием:

- узкие с черешком средней длины (Токмазея, № 1; Гончаровка; Вороцев);

- широкие с нервюрой и черешком средней длины (Суворово, негатив 1);

- широкие с нервюрой и длинным черешком (Старые Буюканы; Градижск, № 1).

По мере выявления новых артефактов предложенная типология может быть дополнена без нарушения общей структуры.

\section{Ареал и хронология}

Общая выборка черешковых наконечников стрел с жальцами (вместе с негативами на литейных формах) в степной и лесостепной зонах Северного Причерноморья составляет 22 экземпляра. Ареал их распространения охватывает всю западную часть региона - между Карпато-Подунавьем и бассейном Днепра (рис. 1).

Находки концентрируются в южной части Среднего Поднепровья (9), Северо-Западном Причерноморье $(5+3$ негатива $=8)$, Верхнем Поднестровье (3); по одному наконечнику найдено в Подолии и Северной Буковине. Bсе известные на сегодняшний день литейные формы для изготовления черешковых наконечников стрел с жальцами происходят из Северо-Западного Причерноморья, что позволяет локализовать здесь один из центров по их изготовлению.

Большая часть упомянутых вещей найдена вне комплексов, что делает их однозначную культурно-хронологическую принадлежность недостоверной. Так, совершенно необоснованным представляется мнение И.К. Свешникова, который отнес наконечник из Гончаровки к почапской группе культуры ХлопицеВеселе эпохи средней бронзы [Свєшніков, 1974 , с. 75 , рис. 23,9 ; Свешников, 1990, с. 64 , рис. 18,14]. Спорной выглядит и отнесение именно к сабатиновской культуре серии наконечников с размывов левого берега Днепра под Градижском.

В Северном Причерноморье все плоские черешковые наконечники стрел с жальцами, контекст находки которых достоверно известен (Магала, Новоселица, Волковка, Гордеевка, Петриков, Старые Буюканы), связаны с закрытыми и замкнутыми комплексами периода $\mathrm{BrD}-\mathrm{HaB}_{1}$ (XIII-X вв. до н.э.). В этих пределах могут быть датированы и все случайные находки из региона. Однако следует отметить, что наиболее ранние комплексы (периода BrD: Магала, Новоселица) расположены в регионах, примыкающих к Карпато-Подунавью и связаны с культурным кругом Сабатиновка-НоаКослоджень.

Рассматриваемый тип бронзовых наконечников стрел в эпоху поздней бронзы нахо- 
дит широкие аналогии от Британии до Ирана и от Греции до Польши.

Единичные находки металлических черешковых двулопастных наконечников стрел известны на памятниках Ближнего Востока еще в 3 тыс. до н.э., однако достаточно широкое распространение они получают лишь в позднем бронзовом веке. Черешковые наконечники с жальцами (тип IV по И.Н. Медведской) характерны для первого периода железного века Ирана (1300/1250-1100 гг. до н.э.); наиболее близкие северопричерноморским наконечники происходят из поздних слоев Тарса и Аладжа Гуюк в Анатолии, датируемые 1250-1100 гг. до н.э. На памятниках Северного Кавказа (кобанская культура), Закавказья, Ирана, Сирии, Анатолии конца II начала I тыс. до н.э. известны стрелы с жальцами, отличающиеся от северопричерноморских несколько более крупными размерами и удлиненным черешком [Погребова, 1977, c. 72-74, табл. 12; Медведская, 1980, с. $23-$ 27 , рис. 1; Ванчугов, 1990, с. 92; Козенкова, 1989, табл. XXXVII, 1]. На основании вышеназванных аналогий В.П. Ванчуговым было выдвинуто предположение о том, что формирование черенковых типов наконечников с пером подтреугольной формы и опущенными жальцами происходило на территории Переднего Востока, откуда они во второй половине II тыс. до н.э. появились в Центральной Европе и Карпатском бассейне [Ванчугов, 1990, с. 92-93].

Однако этот вывод нельзя считать однозначным. Так, черешковые стрелы с пером в виде заостренного листа со слабо выраженными жальцами известны на памятниках синташтинской культуры Приуралья (XVIIXVI вв. до н.э.) [Генинг и др., 1992, рис. 171,3, $185,1-5,186]$. В Центральной и Западной Европе (Швейцария, Бавария, Пфальц, Южная Германия; Франция; Британия) плоские наконечники с жальцами встречаются на памятниках середины - второй половины II тыс. [Müller-Karpe, 1980, taf. 313,38, 347,C,3-4, $348, C, 5,420,15,441, E, 2,5,6,443, C, 15,16,18$, $450, F, 15,462, A, 11,488, E, 3]$ и в целом синхронны своим ближневосточным аналогам. В.П. Ванчугов (несколько пересмотревший свои более ранние взгляды) и И.Т. Черняков отмечают, что плоские треугольные наконечники стрел с опущенными жальцами находят ближайшие аналогии в Микенской Греции, где они были распространены начиная с позднемикенского периода МП-II (1500 г. до н.э.) и продолжали бытовать до так называемого темного периода [Ванчугов, Черняков, 1991, с. 30]. В Румынии плоские наконечники с центральной нервюрой и «шпорой» на черешке происходят из клада Шпэльнака II в Трансильвании, относящегося к периоду НаА (XII в. до н.э.) [Petrescu-Dîmbovița, 1977, p. 109, pl. 202,12,13]. В Польше плоские наконечники с жальцами известны на памятниках лужицкой культуры [Ванчугов, Черняков, 1991, рис. 3,3-5], в которой доживают до периода $\mathrm{HaD}$ (VI в. до н.э.) (рис. 3,10) [Gardawski, 1979, S. 141, Tab. XXXVIII,9].

На наш взгляд, не представляется возможным однозначно сказать, какой из центров - ближневосточный или балкано-дунайский - повлиял на появление плоских металлических стрел с жальцами в Северном Причерноморье. Скорее всего, правомернее ставить вопрос о разновекторных контактах региона, лежащего на путях трансъевразийских коммуникаций. Кроме того, внешние влияния могли наложиться на местные традиции. Так, кремневые черешковые наконечники стрел с жальцами зафиксированы в разных культурах эпохи бронзы Северного Причерноморья, от ее раннего периода до финального: ямной (рис. 5,1) [Razumow, 2011, fig. 16,1], бабинской (рис. 5,2) [Березанская, 1986, рис. 4,10], комаровской (рис. 5,3) [Лысенко, Лысенко, 2017, рис. 9,3], сосницкой (рис. 5,4,8,9) [Березанская, 1972, табл. V,5б; Лысенко, Разумов, 2010, рис. 7,2-3], поздней сосницкой (лебедовской) (рис. 5,5-7) [Шидловський та ін., 2016, рис. 102,4-6], высоцкой (рис. 5,10-13) [Бандрівський, 2014, фото 79], ранней лужицкой (рис. 5,14-15) [Клочко, 2006, рис. 93,1,2]. Даже если не исключать наличие на просторах Евразии некоего первоначального очага формирования подобного типа бронзовых наконечников стрел, в основе их регионального изготовления, возможно, лежит подражание местным кремневым изделиям. Кремневые наконечники такого типа появляются в регионе раньше и, видимо, переживают свои бронзовые аналоги. 


\section{Иные типы бронзовых черешковых наконечников стрел \\ в Северном Причерноморье}

Кроме плоских черешковых наконечников с жальцами в Северном Причерноморье известны и плоские наконечники несколько иных типов - черешковые и бесчерешковые без жалец.

Литейная форма для отливки двух лисmовидных черешковых наконечников стрел с нервюрой найдена в 1961 г. А.В. Бодянским на сабатиновском поселении Высшетарасовка IV (Tapacoвка IV) (Днепропетровская обл., Томаковский р-н). Обломок талькового сланца так же, как и в других случаях, был использован вторично. На плоскостях сохранились плохо различимые следы ранее вырезанных и затем сошлифованных негативов. Размеры литейной формы - $64 \times 35 \times 15$ мм. На верхней плоскости вырезаны два почти одинаковых негатива черешковых удлиненно-листовидных наконечников стрел (рис. 3,13). Длина негативов - 56 мм, длина пера -35 мм, ширина - 7 мм, длина черешка - 21 мм, глубина негатива 2 мм. Поверхность негативов слабо обожжена [Шарафутдинова, 1987, рис. 1,4; Ванчугов, Черняков, 1991, с. 25, рис. 1, 1, 4,7]

В 1973 г. И.И. Артеменко в кургане поздней сосницкой культуры у оз. Голосок (Брянская обл., Жуковский р-н, с. Вщиж) был обнаружен плоский наконечник стрелы треугольной формы с длиннылм черенком (рис. 3,14). Длина (по фото) - около 66 мм, длина пера 42 мм; ширина - 12 мм, ширина черешка - 67 мм [Артеменко, 1987, с. 111, рис. 52,11; Разлуцкая и др., 2013, с. 41, фота 14, 16,1].

Из слоя могильника поздней сосницкой (лебедовской) культуры Бобрица (Черкасская обл., Каневский р-н) происходит железный плоский подтреугольный наконечник с обломанным черешком (рис. 3,12). Длина сохранившейся части - 25 мм; ширина пера - до 12,2 мм; толщина - до 1,6 мм [Даниленко, 1956, c. 16, табл. VIII,11; Березанская, 1976, с. 202, рис. 9,11; Артеменко, 1987, с. 111].

На противоположных берегах Днепра к югу от Киева найдены бронзовые бесчерешковые наконечники в виде высоких треугольников. Один из них, из бронзовой «плоской пластины в виде пирамидки», происходя- щий из с. Вишенки (Киевская обл., Бориспольский р-н), был представлен на XII Археологическом съезде в Харькове в 1902 г. [Каталог..., 1902, с. 108, № 885]. Еще один бронзовый плоский наконечник стрелы в форме высокого треугольника был найден в 1950 г. В.Н. Даниленко у с. Подгорцы (Киевская обл., Обуховский р-н) (рис. 3,11) [Даниленко, 1956, табл. VIII,2]. Перечисленные находки могут быть отнесены к заключительному периоду эпохи поздней бронзы и датированы последней четвертью II - началом I тыс. до н.э.

На заключительном этапе периода поздней бронзы плоские наконечники стрел сосуществуют с втульчатыми наконечниками разных типов [Черняков и др., 1986; Ванчугов, Черняков, 1991]. В раннем железном веке втульчатые наконечники окончательно вытесняют плоские в степи и южной лесостепи Северного Причерноморья. Дальнейшее развитие плоские наконечники листовидной, подромбической и подтреугольной формы, а также плоские бесчерешковые наконечники с двумя шипами находят в культурах подгорцевско-милоградского круга северной лесостепи Северного Причерноморья и Полесья раннего железного века [Даниленко, 1956, табл. V; Мельниковская, 1967, с. 69-70, рис. 29; Вергей, 1995, с. 91, рис. 3,1; Лысенко, 2004, с. 1516 , рис. $2,25,3,2-32,34,43]$.

\section{Заключительные положения}

Плоские черешковые наконечники стрел с жальцами из Северного Причерноморья в позднем бронзовом веке охватывают два основных региона - бассейн Днестра (с прилегающими территориями Нижнего Подунавья, Северной Буковины и Подолии) и южную часть Среднего Поднепровья, связанного с бассейном Днестра южной ветвью трансъевропейского лесостепного пути. На основании находок из закрытых и замкнутых комплексов такие наконечники могут быть датированы в макрорегионе в пределах периода $\mathrm{BrD}-\mathrm{HaB}_{1}$ (XIII$\mathrm{X}$ вв. до н.э.). Толчком к формированию этого типа артефактов могли послужить культурные контакты с балкано-карпатскими и ближневосточными центрами, а также воплощение в металле традиционных форм, известных по кремневым наконечникам стрел. 


\section{ПРИМЕЧАНИЯ}

${ }^{1}$ Благодарим Д.П. Куштана за любезное предоставление копии прорисовки наконечника из черновика отчета Т.Л. Битковской о раскопках на поселении Вовковка в 1991 году. К сожалению, отчет так и не был сдан, а сам наконечник стрелы, похоже, утерян.

2 Упомянутые наконечники стрел были найдены на размывах разрушающихся памятников без применения металлодетекторов и опубликованы еще в советское время. Поэтому републикацию вещей из этих частных коллекций считаем возможной и не относим к популяризации незаконных археологических изысканий. Материалы же с современных сайтов грабителей в настоящей публикации не используются из принципиальных соображений.

${ }^{3}$ В публикациях наконечники стрел из Вороцева и Гончаровки представлены без масштаба. Однако в монографии Н.С. Бандривского [2014] эти наконечники изображены рядом с наконечником из Петрикова, размеры которого известны. Поэто- му на иллюстрациях в настоящей публикации наконечники из Гончаровки и Вроцева приводятся в тех же пропорциях по отношению к наконечнику стрелы из Петрикова, как и в монографии Н.С. Бандривского.

${ }^{4}$ В монографии О. Левицкого [Levițki, 1994] изображение наконечника стрелы ошибочно подано в масштабе 0,7 от натуральной величины. В настоящей публикации приводим изображение наконечника из Старых Буюкан по О. Левицкому [Levițki, 1994], но в соответствии с размерами, приводимыми в монографии В.П. Ванчугова [1990].

${ }^{5}$ Определение кандидата геолого-минералогических наук, доцента Одесского университета Л.В. Ищенко.

${ }^{6}$ Размеры негативов наконечников даны по первой публикации литейной формы [Черняков и др., 1986, с. 48]. В монографии В.П. Ванчугова приводятся несколько иные промеры. № 1: длина негатива - 38 мм, размах лопастей 26 мм. № 2: длина негатива - 22 мм, размах лопастей-16 мм [Ванчугов, 1990, с. 92]. 


\section{ИЛЛЮСТРАЦИИ}

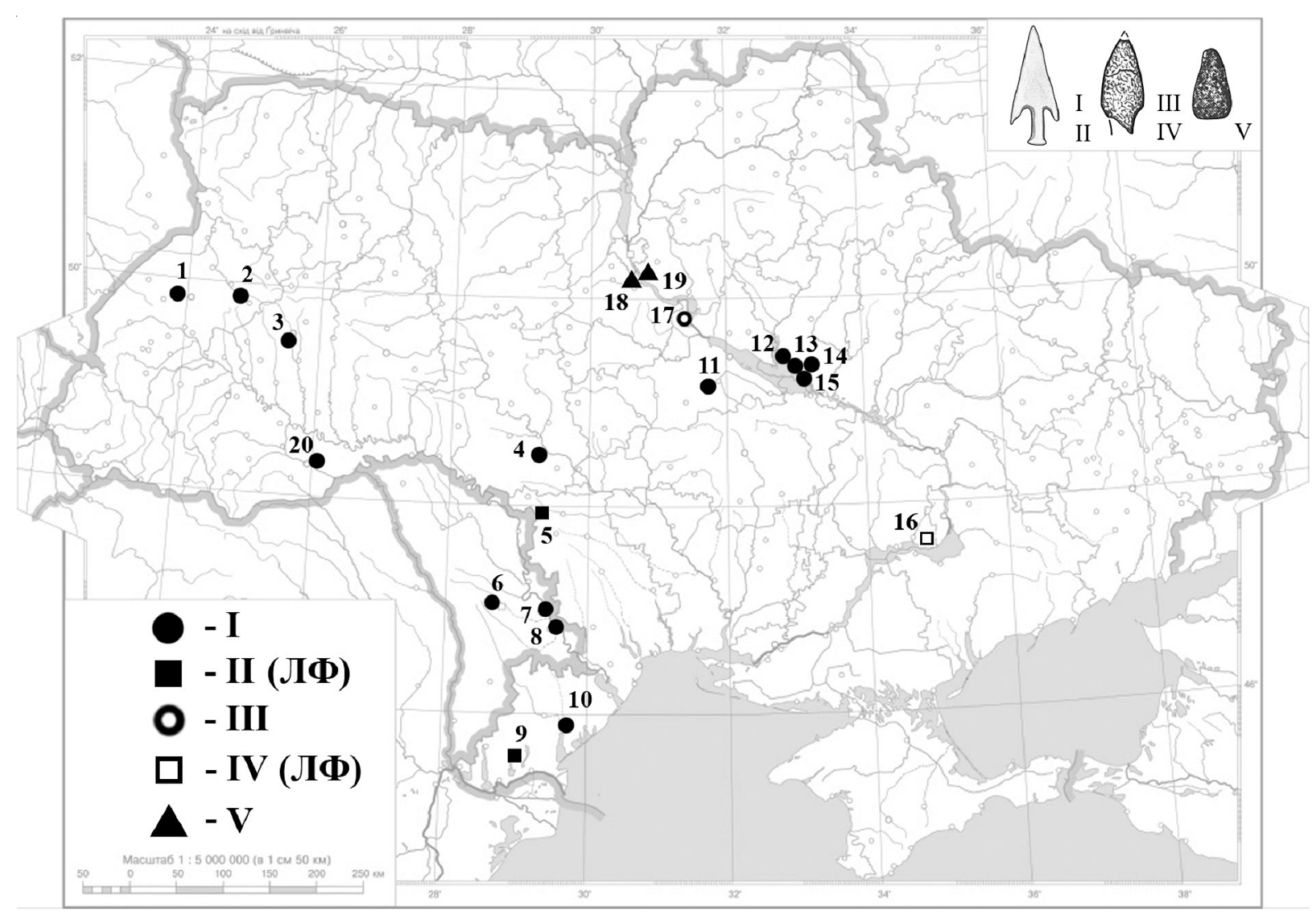

Рис. 1. Распространение бронзовых плоских черешковых и бесчерешковых наконечников стрел заключительного периода эпохи поздней бронзы в Северном Причерноморье:

$I$ - черешковые наконечники стрел с жальцами;

II - литейные формы для отливки черешковых наконечников стрел с жальцами; III - листовидные черешковые наконечники стрел;

$I V$ - литейные формы для листовидных черешковых наконечников стрел; $V$ - бесчерешковые треугольные наконечники стрел.

1 - Вороцев; 2 - Гончаровка; 3 - Петриков; 4 - Гордеевка; 5 - Слободка; 6 - Старые Буюканы; 7 - Токмазея; 8 - Терновка; 9 - Суворово; 10 - Новоселица; 11 - Волковка; 12 - Шушваловка; 13 - Васьковка; 14 - Кагамлык; 15 - Градижск; 16 - Высшетарасовка; 17 - Бобрица; 18 - Подгорцы; 19 - Вишенки; 20 - Магала

Fig. 1. Distribution of bronze flat petiolate and petiolate-free arrowheads of the final period of the Late Bronze Age in the North Black Sea Region:

$I$ - petiolate arrowheads with stings; $I I$ - casting molds for casting petiolate arrowheads with stings; $I I I$ - leaf-shaped petiolate arrowheads; $I V$ - casting molds for leaf-shaped petiolate arrowheads; $V$ - petiolate-free triangle arrowheads.

1 - Vorotsev; 2 - Goncharovka; 3 - Petrikov; 4 - Gordeevka; 5 - Slobodka; 6 - Old Buyukany; 7 - Tokmazeya; 8 - Ternovka; 9 - Suvorovo; 10 - Novoselitsa; 11 - Volkovka; 12 - Shushvalovka; 13 - Vaskovka; 14 - Kagamlyk; 15 - Gradizhsk; 16 - Vyshetsarasovka; 17 - Bobritsa; 18 - Podgortsy; 19 - Vishenki; 20 - Magala 

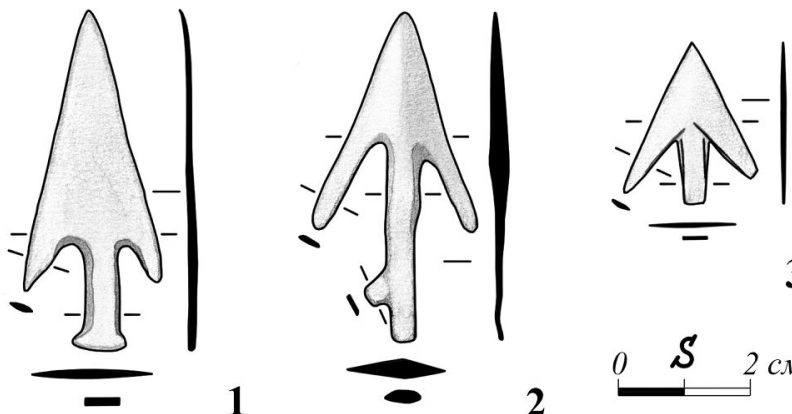

3

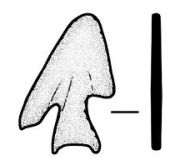

0 $2 \mathrm{cM}$
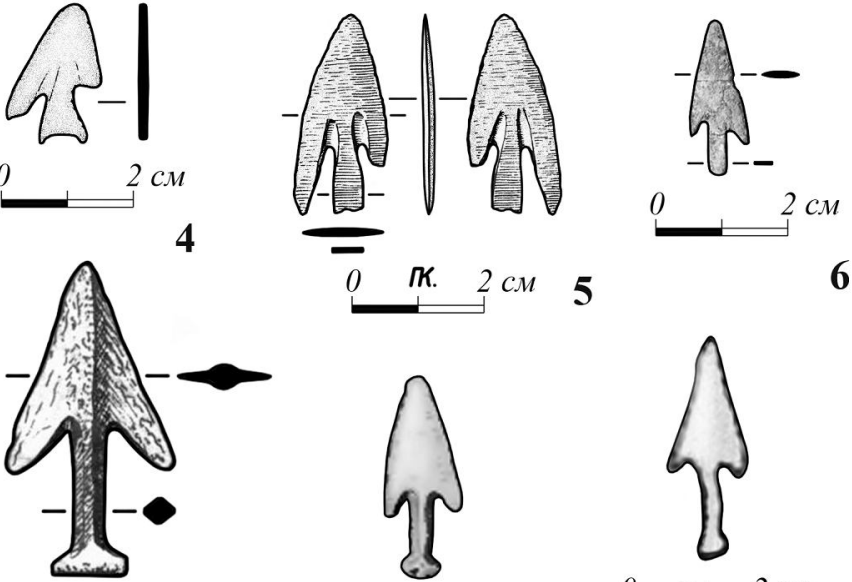

$0 \quad \pi .2 \mathrm{~cm}$

5

6
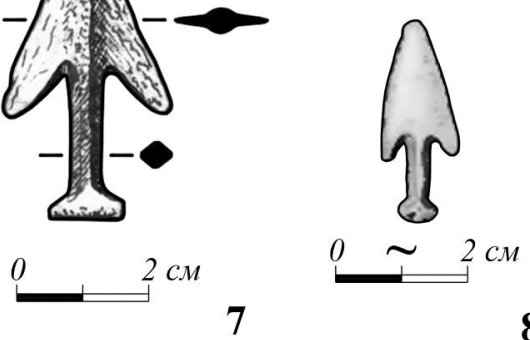

7
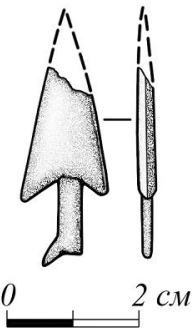

$2 \mathrm{cM}$

10

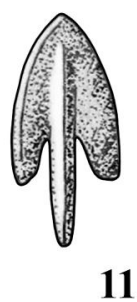

11
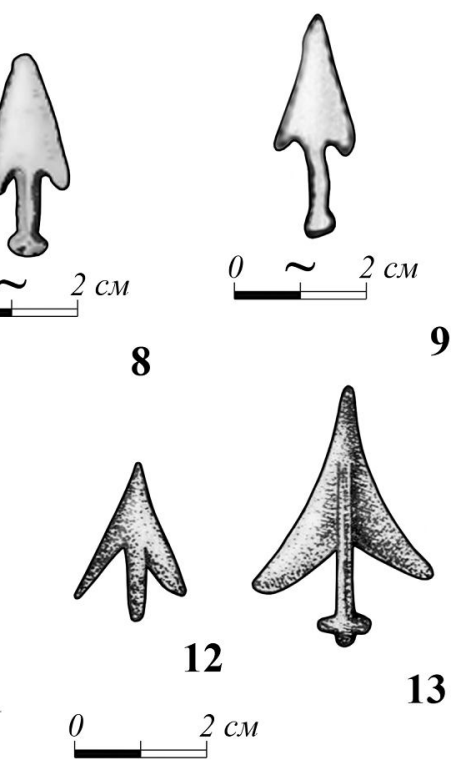

8

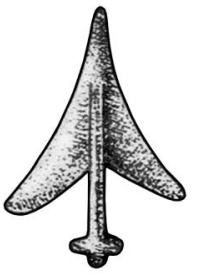

12

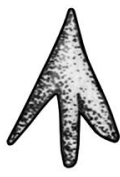

$2 c N$

Рис. 2. Металлические черешковые наконечники стрел с жальцами заключительного периода эпохи поздней бронзы:

1-2 - Токмазея-1; 3 - Терновка-1 (фонды Археологического музея Приднестровья; рис. С.Д. Лысенко); 4 - Волковка (по: [Куштан, 2013, рис. 46,31]); 5 - Гордеевка, кург. 34 (по: [Березанская, Лобай, 1988, табл. XVII,6]); 6 - Петриков, погр. 56 (по: [Бандрівський, 2002, рис. 24,2, фото 80]);

7 - Старые Буюканы (по: [Levițki, 1994, fig. 49,17), масштаб по: [Ванчугов, 1990, с. 93, рис. 35,7]);

8 - Гончаровка (по: [Пастернак, 1932, табл. VIII,2]); 9 - Вороцев (по: [Бандрівський, 2014, рис. 73,14]);

10 - Новоселица (по: [Ванчугов, Черняков, 1991, рис. 1,3]); 11 - Слободка (по: [Ванчугов, 1990, рис. 35,4]); 12-13 - Суворово VI (по: [ Ванчугов, 1990, рис. 35,5-6]).

1-10 - бронза; 11-13 - реконструкция по негативам на литейных формах

Fig. 2. Metal petiolate arrowheads with stings of the final period of the Late Bronze Age:

1-2 - Tokmazeya-1; 3 - Ternovka-1 [funds of the Archaeological Museum of Podnestrovie; drawing by S. D. Lysenko]; 4 - Volkovka (after: [Kushtan, 2013, fig. 46,31]); 5 - Gordeevka, kurgan 34 (after: [Berezanskaya, Lobay, 1988, tab. XVII,6]); 6 - Petrikov, burial 56 (after: [Bandrivsky, 2002, fig. 24,2, photo 80]);

7 - Starye Buyukany (after: [Leviţki, 1994, fig. 49,17], scale after: [Vanchugov, 1990, p. 93, fig. 35,7]);

8 - Goncharovka (after: [Pasternak, 1932, tab. VIII,2]); 9 - Vorotsev (after: [Bandrivsky, 2014, fig. 73,14]);

10 - Novoselitsa (after: [Vanchugov, Chernyakov, 1991, fig. 1,3]); 11 - Slobodka (after: [Vanchugov, 1990, fig. 35,4];

12-13 - Suvorovo VI (after: [Vanchugov, 1990, fig. 35,5-6].

$1-10$ - bronze; $11-13$ - reconstruction after negatives on the casting molds 


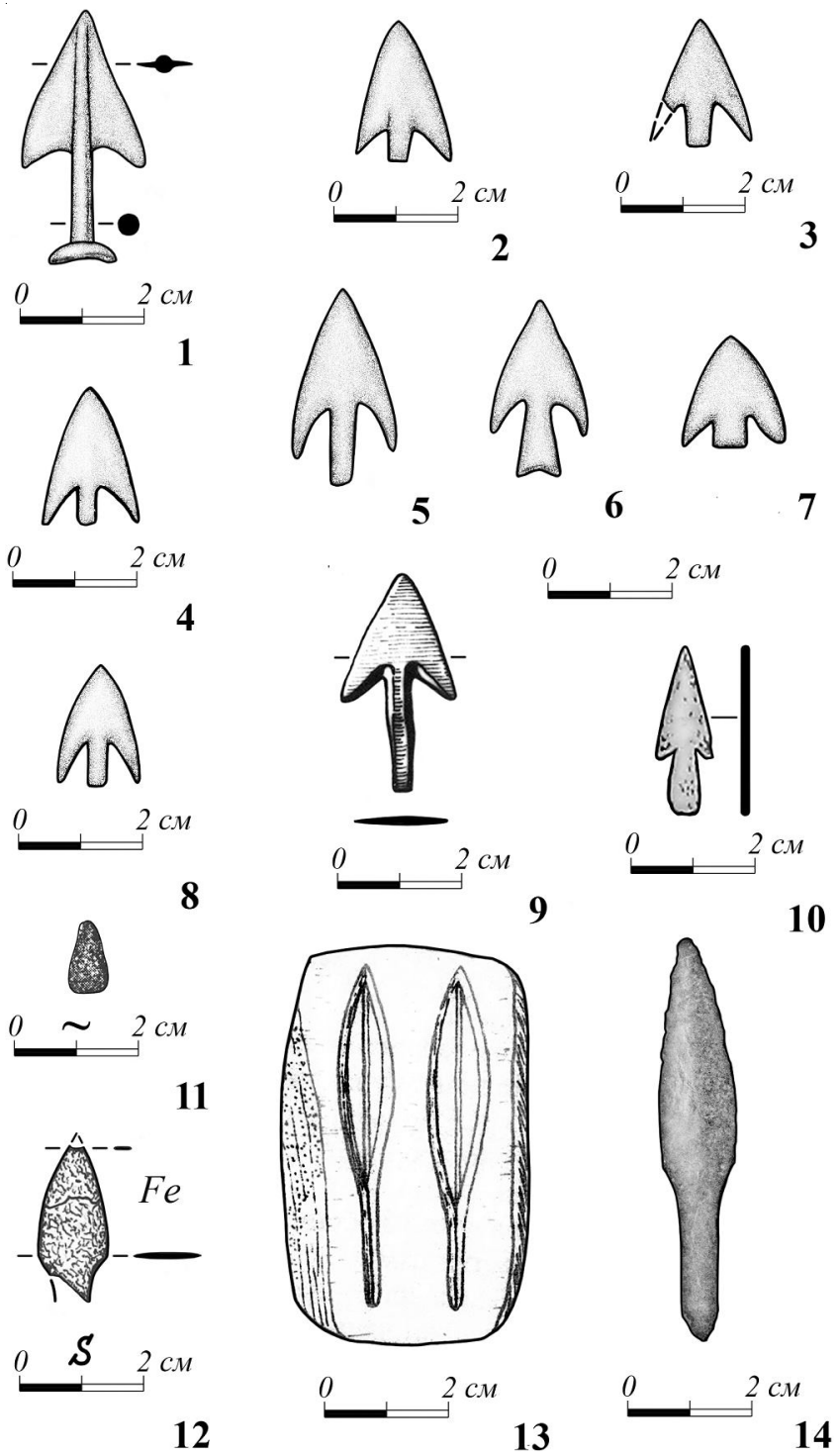

Рис. 3. Металлические черешковые и бесчерешковые наконечники стрел заключительного периода эпохи поздней бронзы:

1-3 - Градижск (по: [Ванчугов, Черняков, 1991, рис. 1,4,11,12]); 4 - Васьковка (по: [Ванчугов, Черняков, 1991, рис. 1,10]); 5-7 - Кагамлык (по: [Ванчугов, Черняков, 1991, рис. 1,7-9]); 8 - Шушваловка (по: [Ванчугов, Черняков, 1991, рис. 1,13]); 9 - Магала, зольник 3 (по: [Смирнова, 1957, с. 4, табл. 11,6]);

10 - Warszawa-Miedzeszyn, gr. 7 (лужицкая культура) (по: [Gardawski, 1979, t. XXXVIII,9]);

11 - Подгорцы (по: [Даниленко, 1956, табл. VIII,2]); 12 - Бобрица (фонды ИА НАНУ; рис. С.Д. Лысенко);

13 - Высшетарасовка-IV (по: [Ванчугов, Черняков, 1991, рис. 1,1]);

14 - Голосок, кург. 1973 г. (по: [Разлуцкая и др., 2013, фота 14]). $1-11,14$ - бронза; 12 - железо; 13 - литейная форма

Fig. 3. Metal petiolate and petiolate-free arrowheads of the final period of the Late Bronze Age:

1-3 - Gradizhsk (after: [Vanchugov, Chernyakov, 1991, fig. 1,4,11,12]);

4 - Vaskovka (after: [Vanchugov, Chernyakov, 1991, fig. 1,10]);

5-7 - Kagamlyk (after: [Vanchugov, Chernyakov, 1991, fig. 1,7-9]);

8 - Shushvalovka (after: [Vanchugov, Chernyakov 1991, fig. 1,13]);

9 - Magala, ashery 3 (after: [Smirnov, 1957, p. 4, tab. 11,6]);

10 - Warszawa-Miedzeszyn, gr. 7 (Luzatian culture) (after: [Gardawski, 1979, t. XXXVIII,9]);

11 - Podgortsy (after: [Danilenko, 1956, tab. VIII,2]);

12 - Bobritsa (funds of the Institute of Archaeology, National Academy of Science of the Ukraine; drawing by S. D. Lysenko);

13 - Vyshesetarasovka-IV (after: [Vanchugov, Chernyakov, 1991, fig. 1,1]);

14 - Golosok, kurgan 1973 (after: [Razlutskaya et al., 2013, photo 14].

1-11,14 - bronze; 12 - iron; 13 - casting mold 

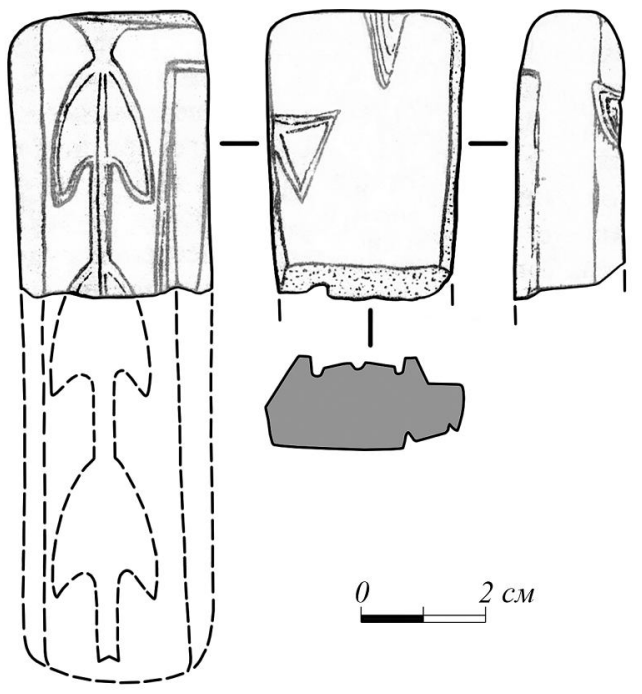

1

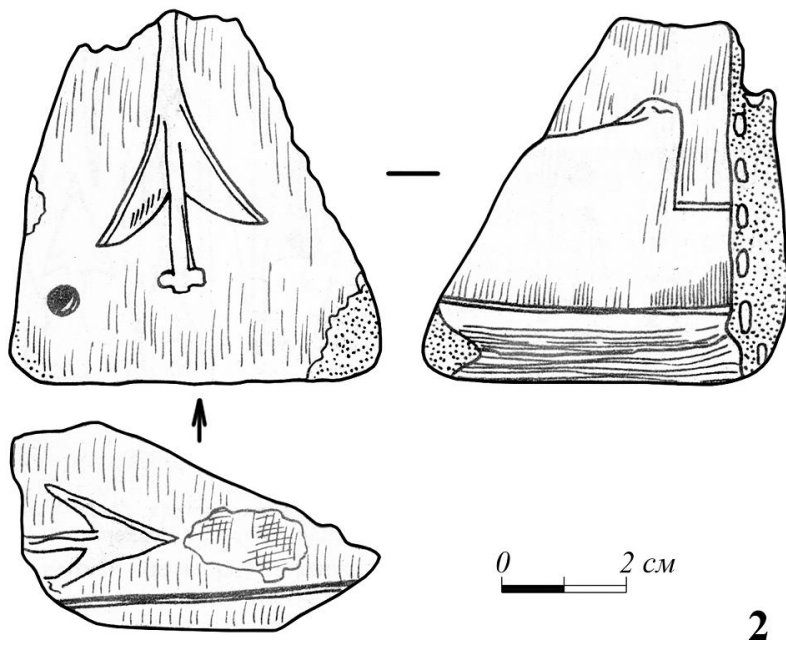

Рис. 4. Литейные формы для отливки металлических черешковых наконечников стрел с жальцами из Северо-Западного Причерноморья:

1 - Слободка (по: [Ванчугов, Черняков, 1991, рис. 1,2];

2 - Суворово VI (по: [Ванчугов, Черняков, 1991, рис. 2,3]

Fig. 4. Casting molds for metal petiolate arrowheads with stings from the North-Western Black Sea region:

1 - Slobodka (after: [Vanchugov, Chernyakov, 1991, fig. 1,2]);

2 - Suvorovo-VI (after: [Vanchugov, Chernyakov, 1991, fig. 2,3]) 


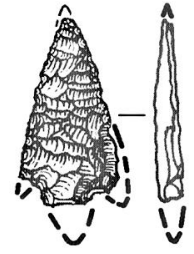

$2 \mathrm{cM}$

1
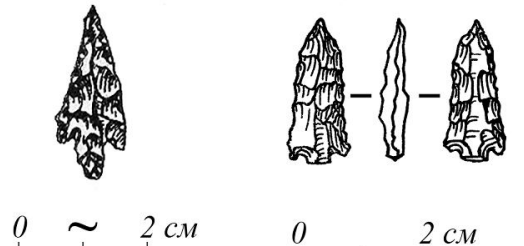

$\stackrel{0}{0} \quad 2 M$

2

3
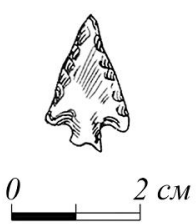

4
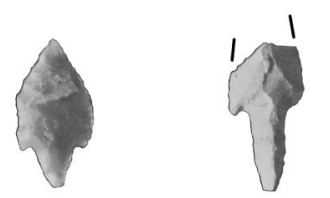

5
6

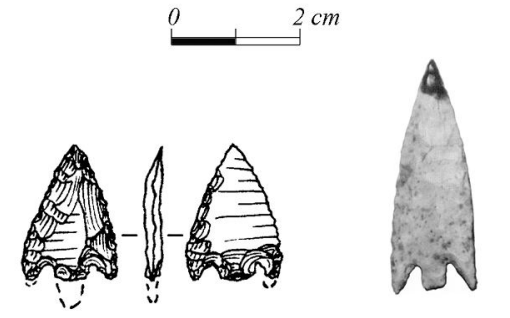

4

8

9

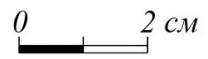

0

$2 \mathrm{CM}$

10
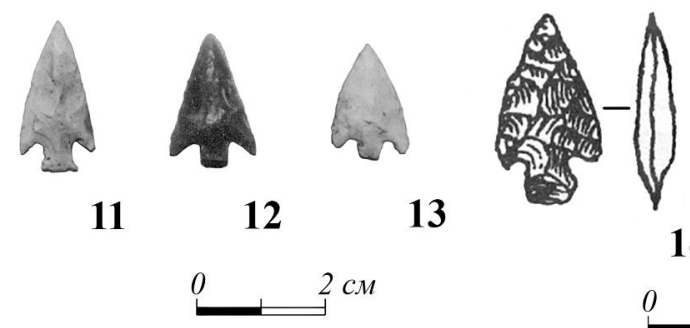

14

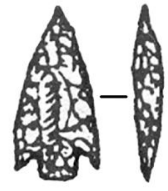

0

15

Рис. 5. Кремневые черешковые наконечники стрел с жальцами из Северного Причерноморья:

1 - Малая Терновка, кург. 1, погр. 1 (по: [Razumow, 2011, fig. 16,1]); 2 - Волынцево (по: [Березанская, 1986, рис. 4,10]);

3 - Войцеховка, кург. группа 5, кург. 1 (по: [Лысенко, Лысенко, 2017, рис. 9,3], рис. С.Н. Разумова); 4 - Здвижевка (по: [Березанская, 1972, табл. V,5-б]);

5-7 - Погребы, ур. Келийки (по: [Шидловський та ін., 2016, рис. 102,4-6];

8-9 - Ходосовка, ур. Диброва, объект 19 (по: [Лысенко, Разумов, 2010, рис. 7,3], рис. С.Н. Разумова); 10-13 - Петриков, погр. 91 (по: [Бандрівський, 2002, фото 79]); 14 - Рованцы (по: [Клочко, 2006, рис. 93,1]); 15 - Тяглов (по: [Клочко, 2006, рис. 93,2])

Fig. 5. Flint petiolate arrowheads with stings from the territory of the Northern Black Sea Region:

1 - Malaya Ternovka, kurgan 1, burial 1 (after: [Razumow, 2011, fig. 16,1]); 2 - Volintsevo (after: [Berezanskaya, 1986, fig. 4,10]);

3 - Wojciechovka, kurgan group 5, kurgan 1 (after: [Lysenko, Lysenko, 2017, fig. 9,3], fig. by S. N. Razumov); 4 - Zdvizhevka (after: [Berezanskaya, 1972, tab. V,5-6];

5-7 - Pogreby, Keliyki tract (after: [Shidlovsky et al., 2016, fig. 102,4-6]);

8-9 - Khodosovka, Dibrova tract, object 19 (after: [Lysenko, Razumov, 2010, fig. 7,3], fig. by S. N. Razumov); 10-13 - Petrikov, burial 91 (after: [Bandrivsky, 2002, photo 79]); 14 - Rovantsy (after: [Klochko, 2006, fig. 93,1]); 15 - Tyaglov (after: [Klochko, 2006, fig. 93,2]) 


\section{СПИСОК ЛИТЕРАТУРЫ}

Артеменко И. И., 1987. Сосницкая культура // Археология СССР. Эпоха бронзы лесной полосы СССР. М. : Наука. С. 106-113.

Бандрівський М. С., 2002. Могильник в Петрикові біля Тернополя в контексті поховального обряду висоцької культури. Львів : Логос. 282 с.

Бандрівський М. С., 2014. Культурно-історичні процеси на Прикарпатті і Західному Поділлі в пізній період епохи бронзи - на початку доби раннього заліза. Львів : Інститут українознавства ім. І. Крипякевича НАН України. $573 \mathrm{c}$.

Березанская С. С., 1972. Средний период бронзового века в Северной Украине. Киев : Наукова думка. 267 с.

Березанская С. С., 1976. Лебедовская культура эпохи бронзы в лесостепной Украине // Энеолит и бронзовый век Украины. Киев : Наукова думка. С. 190-222.

Березанская С. С., 1986. Культура многоваликовой керамики // Березанская С. С., Отрощенко В. В., Чередниченко Н. Н., Шарафутдинова И. Н. Культуры эпохи бронзы на территории Украины. Киев : Наукова думка. С. 5-43.

Березанська С. С., Клочко В. І., 2011. Гордіївский могильник // Гордіївский могильник. Вінниця : Рятівна археологічна служба. С. 7-113.

Березанская С. С., Лобай Б. И., 1988. Отчет о раскопках могильника эпохи бронзы у с. Гордеевка Тростянецкого р-на Винницкой обл. в 1988 г. // Научный архив ИА НАНУ. № 1988/5. 21 с., XLII табл.

Бочкарев В. С., Кашуба М. Т., 2018. Культурно-историческая ситуация на юге Восточной Европы накануне века железа // Stratum plus. № 3. C. 207-220.

Ванчугов В. П., 1990. Белозерские памятники в Северо-Западном Причерноморье. Проблемы формирования белозерской культуры. Киев : Наукова думка. 166 с.

Ванчугов В. П., Черняков И. Т., 1991. Металлические наконечники стрел сабатиновской и белозерской культур // Северо-Западное Причерноморье - контактная зона древних культур. Киев : Наукова думка. C. 24-37.

Вергей В. С., 1995. Западный ареал милоградской культуры // Гістарычна-археалагічны зборнік. № 7. Минск : Інстытуг гісторыі АН Беларусі. С. 83-100.

Генинг В. Ф., Зданович Г. Б., Генинг В. В., 1992. Синташта: археологические памятники арийских племен Урало-Казахстанских степей. Ч. 1. Челябинск : Юж.-Урал. кн. изд-во. 408 с.

Даниленко В. М., 1956. Дослідження пам'яток підгірського та бобрицького типів на Київщині в 1950 р. // Археологічні памятки УРСР. Т. 6. Київ : Інститут археології АН УРСР. С. 5-16.

Каталог выставки ХІІ Археологическаго съезда въ г. Харькове / Уварова П. С. (ред.). Харьков, 1902. 933 с.

Клочко В. І., 2006. Озброєння та військова справа давнього населення України (5000-900 pp. до Р.Х). Київ : АртЕк. 336 с.

Козенкова В. И., 1989. Кобанская культура. Западный вариант. САИ. Вып. В2-5. М. : Наука. 196 с.

Куштан Д. П., 2013. Південь Лісостепового Подніпровя за доби пізньої бронзи. Археологічний альманах. № 29. Донецьк : Донбас. $232 \mathrm{c}$.

Лысенко С. Д., 2004. Погребения скифского времени Малополовецкого могильника // Археологічні пам'ятки Фастівщини. Матеріали до археологічної карти Київської області. Прес-музей. № 20-21. Фастів : ФДКМ. C. 6-33.

Лысенко С. Д., Гуцул А. В., Синика В. С., 2020. Наконечники стрел эпохи поздней бронзы с левобережья Нижнего Днестра // FORUM OLBICUM III: До 70-річчя з дня народження В. В. Крапівіної : (Матеріали міжнародної археологічної конференції, 4-6 травня 2020 р.). Миколаїв : Науково-дослідний центр «Лукоморє». С. 30-33.

Лысенко С. Д., Лысенко С. С., 2017. Курганоподобные возвышения с территории Войцеховского могильника (по результатам исследований 2013 г.) // Новое прошлое. № 4. Ростов н/Д : Юж. федер. ун-т. C. 264-285.

Лысенко С. Д., Разумов С. Н., 2010. Кремневые изделия эпохи бронзы многослойного поселения ХодосовкаДиброва на Киевщине // Матэрыялы па археалогіi Беларусі. Вып. 18. Минск : Інстытут гісторыі АН Беларусі. С. 261-278. 
Медведская И. Н., 1980. Металлические наконечники стрел Переднего Востока и Евразийских Степей II первой половины І тысячелетия до н.э. // Советская археология. № 4. С. 23-37.

Мельниковская О. Н., 1967. Племена Южной Белоруссии в раннем железном веке. М. : Наука. 196 с.

Пастернак Я., 1932. Коротка археольогія західно-українських земель. Львів : Біблос. 96 с.

Погребова М. Н., 1977. Иран и Закавказье в раннем железном веке. М. : Наука. 184 с.

Разлуцкая А. А., Язэпенка І. М., Лысенка С. Д., Лысенка С. С., 2013. Археалагічныя калекцыі I.I. Арцёменкі (1956-1981 гг.). Збор крыніц навуковых археалагічных фондаў. Вып. 1. Мінск : Беларуская навука. 224 с.

Смирнова Г. И., 1957. Экспедиционный отчет о раскопках поселения возле с. Магала Черновицкой области // Научный архив ИА НАНУ. № 1957/22. 17 с., 18 табл.

Смирнова Г. И., 1969. Поселение Магала - памятник древнефракийской культуры в Прикарпатье (вторая половина XIII - середина VII в. до н.э.) // Древние фракийцы в Северном Причерноморье. М. : Наука. С. 7-34.

Свєшніков I. К., 1974. Історія населення Передкарпаття, Поділля і Волині в кінці III - на початку II тисячоліття до нашої ери. Київ : Наукова думка. 208 с.

Свешников И. К., 1990. Почапская группа культуры Хлопице-Веселе // Археология Прикарпатья, Волыни и Закарпатья (энеолит, бронза и раннее железо). Киев : Наукова думка. С. 63-65.

Тощев Г. Н., Черняков И. Т., 1986. Культовые зольники сабатиновской культуры // Исследования по археологии Северо-Западного Причерноморья. Киев : Наукова думка. С. 115-138.

Черняков И. Т., Ванчугов В. П., Кушнир В. Г., 1986. Древнейшие бронзовые наконечники стрел Северного Причерноморья // Советская археология. № 2. С. 47-55.

Шарафутдинова И. Н., 1987. Бронзовые украшения сабатиновской культуры (к вопросу о контактах) // Межплеменные связи эпохи бронзы на территории Украины. Киев : Наукова думка. С. 69-86.

Шидловський П. С., Лисенко С. Д., Кириленко О. С., Сорокун А. А., Пічкур С. В., 2016. Первісна археологія Нижнього Подесення. Київ : Кафедра археології та музеєзнавства КНУ ім. Т. Шевченка. 344 с.

Berezanskaja S. S., Kločko V. I., 1998. Das Gräberfeld von Hordeevka. Archäologie in Eurasien. 5. Rahden ; Westf. 87 s., 83 taf.

Gardawski A., 1979. Czasy zaniku kultury łużyckiej. Okres halsztacki D i lateński // Prahistoria ziem polsrich, IV (Od śrokowej epoki brązu do śrokowego okresu lateńskiego). Wroclaw, Warczawa, Gdansk : Ossolineum. S. 117-146.

Levițki O., 1994. Cultura hallstattului canelat la răsărit de Carpați. Bibliotheca thracologica. VII. Bucureşti : Institutul Român de Tracologie. 255 p.

Müller-Karpe H., 1980. Bronzezeit. Dritter teilband, tafeln. Handbuch der vorgeschichte. IV. Munchen : C. H. Beck'sche Verlagsbuchhandlung. 602 taf.

Petrescu-Dîmbovița M., 1977. Depozitele de bronzuri din România. Bucureşti: Editura Academiei Republicii Socialiste România. 391 p.

Razumow S.M., 2011. Flint artefacts of Northern Pontic populations of the early and middle Bronze Age: 3200-1600 BC. Baltic-Pontic Studies, vol. 16. Poznań : Uniwersytet im. Adama Mickiewicza w Poznaniu. 326 p.

\section{REFERENCES}

Artemenko I.I., 1987. Sosnitskaia kultura [Sosnitskaya Culture]. Arkheologiia SSSR. Epokha bronzy lesnoi polosy SSSR [Archaeology of the USSR. The Bronze Age of the USSR Forest Band]. Moscow, Nauka Publ., pp. 106-113.

Bandrivsky M.S., 2002. Mohylnyk v Petrykovi bilia Ternopolia v konteksti pokhovalnoho obriadu vysotskoi kultury [Cemetery in Petrykiv near Ternopil in the Context of the Funerary Rite of Vysotskaya Culture]. Lviv, Lohos Publ. 282 p.

Bandrivsky M.S., 2014. Kulturno-istorychni protsesy na Prykarpatti i Zakhidnomu Podilli v piznii period epokhy bronzy - na pochatku doby rannoho zaliza [Cultural and Historical Processes in Sub-Carpathian and West Podillian Regions During the Late Period of Bronze Age - Beginning of Early Iron Age]. Lviv, Institute of Ukrainian Studies named after I. Krypiakevych NAS of Ukraine. 573 p.

Berezanskaya S.S., 1972. Sredniy period bronzovogo veka v Severnoy Ukraine [Middle Bronze Age in Northern Ukraine]. Kiev, Naukova dumka Publ. 267 p. 
Berezanskaya S.S., 1976. Lebedovskaya kultura epokhi bronzy v lesostepnoy Ukraine [Lebedovskaya Culture of the Bronze Age in the Forest-Steppe Ukraine]. Eneolit i bronzovyy vek Ukrainy [Eneolithic and Bronze Age of Ukraine]. Kiev, Naukova dumka Publ., pp. 190-222

Berezanskaya S.S., 1986. Kultura mnogovalikovoy keramiki [Multi-cordoned Ware Culture]. Berezanskaya S.S., Otroshchenko V.V., Cherednichenko N.N., Sharafutdinova I.N. Kultury epokhi bronzy na territorii Ukrainy [The Bronze Age Cultures on the Territory of the Ukraine]. Kiev, Naukova dumka Publ., pp. 5-43.

Berezanska S.S., Klochko V.I., 2011. Hordiivskyy mohylnyk [The Gordeevka Cemetery]. Hordiivskyy mohylnyk [The Gordeevka Cemetery]. Vinnytsia, Riativna arkheolohichna sluzhba, pp. 7-113.

Berezanskaya S.S., Lobay B.I., 1988. Otchet o raskopkakh mogilnika epokhi bronzy u s. Gordeevka Trostianetskogo r-na Vinnitskoy obl. v 1988 g. [Report on the Excavation of the Bronze Age Cemetery near Gordeevka Village, Trostyanets District, Vinnitsa Region, in 1988]. Nauchnyy arkhiv IA NANU, no. 1988/5. 21 p., XLII fig.

Bochkarev V.S., Kashuba M.T., 2018. Kulturno-istoricheskaya situatsiya na yuge Vostochnoy Evropy nakanune veka zheleza [Cultural and Historical Situation in the South of Eastern Europe on the Eve of the Iron Age]. Stratum plus, no. 3, pp. 207-220.

Vanchugov V.P., 1990. Belozerskie pamiatniki v Severo-Zapadnom Prichernomore. Problemy formirovaniya belozerskoy kultury [Belozerka Sites in the North-West Black Sea Region. Problems of Formation of the Belozerka Culture]. Kiev, Naukova dumka Publ. 166 p.

Vanchugov V.P., Cherniakov I.T., 1991. Metallicheskie nakonechniki strel sabatinovskoy i belozerskoy kultur [Metal Arrowheads of the Sabatinovka and Belozerka Cultures]. Severo-Zapadnoe Prichernomore-kontaktnaya zona drevnikh kultur [North-West Black Sea Region as Contact Zone of Ancient Cultures]. Kiev, Naukova dumka Publ., pp. 24-37.

Vergei V.S., 1995. Zapadnyy areal milogradskoy kultury [Western Area of Milograd Culture]. Gistarychna arkhealagichny zbornik [Historical and Archaeological Collection], no. 7. Minsk, Institute of History of the Academy of Sciences of Belarus, pp. 83-100.

Gening V.F., Zdanovich G.B., Gening V.V., 1992. Sintashta: arkheologicheskie pamiatniki ariiskikh plemen UraloKazakhstanskikh stepey [Sintashta: Archaeological Sites of the Aryan Tribes of the Ural-Kazakhstan Steppes]. Part 1. Chelabinsk, Iuzhno-Uralskoe knizhnoe izdatelstvo Publ. 408 p.

Danylenko V.M., 1956. Doslidzhennia pamiatok pidhirskoho ta bobrytskoho typiv na Kyivshchyni v 1950 r. [Investigations of Sites of Podgortsy and Bobritsa Types in Kyiv Region in 1950]. Arkheolohichni pamiatky URSR [Archaeological Sites of the USSR], no. 6. Kyiv, Institute of archaeology of Academy of Science of Ukrainian Soviet Socialist Republic, pp. 5-16.

Uvarova P.S., ed. Katalog vystavki XII Arkheologicheskago sieezda vg. Kharkove, 1902 [Catalog of the Exhibition of the $12^{\text {th }}$ Archaeological Congress in Kharkov]. Kharkov. 933 p.

Klochko V.I., 2006. Ozbroiennia ta viiskova sprava davnoho naselennia Ukrainy (5000-900 rr. do R. Kh) [Weapon and Military Equipment of the Ancient Population of Ukraine (5000-900 BC)]. Kyiv, ArtEk Publ. 336 p.

Kozenkova V.I., 1989. Kobanskaya kultura. Zapadnyy variant [Koban Culture. Western Variant]. Svod Arkheologicheskih Istochnikov, iss. B2-6. Moscow, Nauka Publ. 196 p.

Kushtan D.P., 2013. Pivden Lisostepovoho Podniprovia za doby piznoi bronzy [South of the Forest-Steppe Dnieper Region in the Late Bronze Age]. Arkheolohichnyi almanakh, no. 29. Donetsk, Donbas Publ. 232 p.

Lysenko S.D., 2004. Pogrebeniya skifskogo vremeni Malopolovetskogo mogilnika [Burials of the Scythian Time of the Malopolovetskoe Cemetery]. Arkheolohichni pamiatky Fastivshchyny. Materialy do arkheolohichnoi karty Kyivskoi oblasti. Pres-muzey [Archaeological Sites of Fastov Region. Materials for the Archeological Map of Kyiv Region. Press museum], no. 20-21. Fastiv, FDKM Publ., pp. 6-33.

Lysenko S.D., Gutsul A.V., Sinika V.S., 2020. Nakonechniki strel epokhi pozdney bronzy s levoberezhya Nizhnego Dnestra [Arrowheads of the Late Bronze Age from the Left Bank of the Lower Dniester]. FORUM OLBICUM III: Do 70-richchia z dnya narodzhennya V.V. Krapivinoy: (Materialy mizhnarodnoy arkheolohichnoy konferentsii, 4-6 travnia 2020 r.) [FORUM OLBICUM III: To the $70^{\text {th }}$ Anniversary of the Birth of V. V. Krapivina (Proceedings of the International Archaeological Conference, May 4-6, 2020)]. Mykolaiv, Naukovo-doslidnyi tsentr «Lukomorie», pp. 30-33.

Lysenko S.D., Lysenko S.S., 2017. Kurganopodobnye vozvysheniya s territorii Voitsekhovskogo mogilnika po rezultatam issledovaniy $2013 \mathrm{~g}$. [Kurgan-like Elevations from the Territory of the Wojciech Cemetery(According to the Results of Studies in 2013)]. Novoe proshloe [New past], no. 4. Rostov, SFU, pp. 264-285. 
Lysenko S.D., Razumov S.N., 2010. Kremnevye izdeliya epokhi bronzy mnogosloinogo poseleniya KhodosovkaDibrova na Kievshchine [Flint Products of the Bronze Age of the Multilayer Settlement of KhodosovkaDibrova in the Kiev Region]. Materyjaiy pa archieaiohii Bieiarusi [Materials on Archeology of the Belarus], no. 18. Minsk, Institute of History of the Academy of Sciences of Belarus, pp. 261-278.

Medvedskaya I.N., 1980. Metallicheskie nakonechniki strel Perednego Vostoka i Evraziyskikh Stepey II - pervoy poloviny I tysiacheletiya do n. e. [Metal Arrowheads of the of the $\mathrm{II}^{\text {nd }}$ - First Half of the $\mathrm{I}^{\mathrm{st}}$ Millennium B.C. from the Near East and Eurasian Steppes]. Sovetskaya arkheologiya [Soviet Archaeology], no. 4, pp. 23-37.

Melnikovskaya O.N., 1967. Plemena Iuzhnoy Belorussii v rannem zheleznom veke [Tribes of Southern Belarus in the Early Iron Age]. Moscow, Nauka Publ. 196 p.

Pasternak Ya., 1932. Korotka arkheolohiya zakhidno-ukrainskykh zemel [A Brief Archaeology of the Western Ukrainian Lands]. Lviv, Biblos Publ. 96 p.

Pogrebova M.N., 1977. Iran i Zakavkazye v rannem zheleznom veke [Iran and Transcaucasia in the Early Iron Age]. Moscow, Nauka Publ. 184 p.

Razłuckaja A.A., Jazepienka I.M., Łysienka S.D., Łysienka S.S., 2013. Archieałahičnyja kalekcyi I.I. Arciomienki (1956-1981 hh.) [The Archaeological Collection of the I.I. Artemenko (1956-1981)]. Zbor krynic navukovych archieałahičnych fondaŭ, iss. 1. Minsk, Bieiaruskaja navuka Publ. 224 p.

Smirnova G.I., 1957. Ekspeditsionnyy otchet o raskopkakh poseleniya vozle s. Magala Chernovitskoy oblasti [Expeditionary Report on Excavations of a Settlement near the Village of Magala, Chernovtsy Region]. Nauchnyy arkhiv NANU, no. 1957/22. 17 p., 18 fig.

Smirnova G. I., 1969. Poselenie Magala - pamiatnik drevnefrakiyskoy kultury v Prikarpatye (vtoraya polovina XIII seredina VII v. do n. e.) [The Magala Settlement - the Site of Ancient Thracian Culture in the Carpathian Region (Second Half of the $13^{\text {th }}$ - the Middle of the $7^{\text {th }}$ Century BC)]. Drevnie frakiytsy $v$ Severnom Prichernomore [Ancient Thracians in the North Black Sea Region]. Moscow, Nauka Publ., pp. 7-34.

Svieshnikov I.K., 1974. Istoriia naselennia Peredkarpattia, Podillia i Volyni v kintsi III - na pochatku II tysiacholittia do nashoy ery [History of the Population of Precarpathia, Podolia and Volynia in the Late $3^{\text {rd }}-$ Early $2^{\text {nd }}$ Millennium BC]. Kyiv, Naukova dumka Publ. 208 p.

Svieshnikov I.K., 1990. Pochapskaya gruppa kultury Khlopitse-Vesele [Pochap Group of the Khlopice-Vesele Culture]. Arkheologiia Prikarpatia Volyni i Zakarpatia (eneolit, bronza i rannee zhelezo) [Archaeology of Carpathian, Volynian and Transcarpathian (Eneolithic, Bronze and Early Iron Age)]. Kiev, Naukova dumka Publ., pp. 63-65.

Toshchev G.N., Cherniakov I.T., 1986. Kultovye zolniki sabatinovskoy kultury [The Cult Ashers of the Sabatinovka Culture]. Issledovaniya po arkheologii Severo-Zapadnogo Prichernomorya [Archaeology Studies of the Northwest Black Sea Region]. Kiev, Naukova dumka Publ., pp. 115-138.

Cherniakov I.T., Vanchugov V.P., Kushnir V.G., 1986. Drevneishie bronzovye nakonechniki strel Severnogo Prichernomorya [The Earliest Bronze Arrowheads of the Northern Pontic Area]. Sovetskaya arkheologiya [Soviet Archaeology], no. 2, pp. 47-55.

Sharafutdinova I.N., 1987. Bronzovye ukrasheniya sabatinovskoy kultury (k voprosu o kontaktakh) [Bronze Adornments of the Sabatinovka Culture (to the Question of Contacts)]. Mezhplemennye sviazi epokhi bronzy na territorii Ukrainy [Tribal Relations of the Bronze Age in the Ukraine]. Kiev, Naukova dumka Publ., pp. 69-86.

Shydlovskyy P.S., Lysenko S.D., Kyrylenko O.S., Sorokun A.A., Pichkur Ye.V., 2016. Pervisna arkheolohiia Nyzhnoho Podesennia [Prehistoric Archaeology of the Lower Desna Region]. Kyiv, Taras Shevchenko National University of Kyiv. 344 p.

Berezanskaja S.S., Kločko V.I. 1998. Das Gräberfeld von Hordeevka. Archäologie in Eurasien, no. 5.87 s., 83 taf.

Gardawski A., 1979. Czasy zaniku kultury łużyckiej. Okres halsztacki D i lateński. Prahistoria ziem polsrich, IV (Od śrokowej epoki brazu do śrokowego okresu lateńskiego). Wroclaw, Warczawa, Gdansk, Ossolineum, S. 117-146.

Levițki O., 1994. Cultura hallstattului canelat la răsărit de Carpați. Bibliotheca thracologica, no. VII. Bucureşti, Institutul Român de Tracologie. 255 p.

Müller-Karpe H., 1980. Bronzezeit (Dritter teilband, tafeln). Handbuch der vorgeschichte, no. IV. Munchen, C. H. Beck'sche Verlagsbuchhandlung. 602 taf.

Petrescu-Dîmbovița M., 1977. Depozitele de bronzuri din România. Bucureşti, Editura Academiei Republicii Socialiste România. 391 p.

Razumow S.M., 2011. Flint artefacts of Northern Pontic populations of the early and middle Bronze Age: 3200 1600 BC. Baltic-Pontic Studies, vol. 16. Poznań, Uniwersytet im. Adama Mickiewicza w Poznaniu. 326 p. 
S.D. Lysenko, V.S. Sinika, A.V. Gutsul. Bronze Flat Arrowheads with Stings from the North Black Sea Region

\section{Information About the Authors}

Sergey D. Lysenko, Candidate of Sciences (History), Senior Researcher, Department of the Chalcolithic and the Bronze age, Institute of Archaeology, National Academy of Sciences of Ukraine, prosp. Geroev Stalingrada, 12, 04210 Kiev, Ukraine, suraganga@yandex.ru, https://orcid.org/0000-0001-9624-0364

Vitalij S. Sinika, Candidate of Sciences (History), Head of Scientific Laboratory "Archaeology", Pridnestrovian State University, 25 October St, 107, 3300 Tiraspol, Pridnestrovie, Moldova, sinica80@mail.ru, https://orcid.org/0000-0002-1621-9205

Aleksandr V. Gucul, Junior Researcher, Scientific Laboratory “Archaeology”, Pridnestrovian State University, 25 October St, 107, 3300 Tiraspol, Pridnestrovie, Moldova, guntz82@rambler.ru, https://orcid.org/0000-0002-8289-9755

\section{Информация об авторах}

Сергей Дмитриевич Лысенко, кандидат исторических наук, старший научный сотрудник отдела энеолита - бронзового века, Институт археологии Национальной академии наук Украины, просп. Героев Сталинграда, 12, 04210 г. Киев, Украина, suraganga@yandex.ru, https://orcid.org/ 0000-0001-9624-0364

Виталий Степанович Синика, кандидат исторических наук, заведующий научноисследовательской лабораторией «Археология», Приднестровский государственный университет, ул. 25 Октября, 107, 3300 г. Тирасполь, Приднестровье, Молдова, sinica80@mail.ru, https://orcid.org/0000-0002-1621-9205

Александр Вячеславович Гуцул, младший научный сотрудник научно-исследовательской лаборатории «Археология», Приднестровский государственный университет, ул. 25 Октября, 107, 3300 г. Тирасполь, Приднестровье, Молдова, guntz82@rambler.ru, https:/orcid.org/0000-0002-8289-9755 